REFLECTIONS:

NEUROLOGY AND THE

HUMANITIES

Section Editor

Michael H. Brooke, MD

\section{The case of the misguided Squire}

Robert J. Joynt, MD, PhD

Address correspondence and reprint requests to Dr. Robert J. Joynt, Department of Neurology, University of Rochester, 601 Elmwood Avenue, Box 673, Rochester, NY 14642 robert_joynt@urmc.rochester.edu
Three days of fog had finally disappeared, and the morning sun was shining brightly. It lifted the spirits of Holmes and me, who had sulked in our sitting rooms. It also put an end to the noisome chemical experiments that Holmes always turned to when unoccupied with a case. Holmes suggested we go out to lunch when Mrs. Hudson knocked on our door and informed us that we had an unexpected visitor. Holmes assented to see the visitor, and Mrs. Hudson ushered in a stately woman in her middle years. She introduced herself as Mrs. Agatha Fletcher from Braxton. She explained that Braxton was a small fishing and boating port east of London on the North Sea.

Holmes made the necessary introduction of himself and me, and immediately inquired about the purpose of her visit.

She was somewhat distraught, but explained her troubles in a concise manner. "It is my husband Alfred, who is known locally as the Squire, as his family owned most of the land north of the village and Fletchers have lived in the manse for over 200 years. Two days ago, a local young man, Aubrey Pound, was assaulted and received a heavy blow to the head, and he is now in hospital. He is recovering and can give only a sketchy description of his assailant. My husband was close to the place of the assault. It was in a part of the village that he never visits, and he cannot give a good reason why he walked there. $\mathrm{He}$ knows the area, for as a young man, he surveyed the whole region and knows it like the back of his hand. Because of his confusion and the nature of the crime, he is temporarily at the local constabulary and is held there until they can get more evidence."

"Thank you, Mrs. Fletcher, that is a good summation. Now, a few questions: First, you know your husband well. Is he capable of such behavior?" asked Holmes.

She replied, "Indeed, he is a man of fiery disposition, and I cannot say that he has not made some enemies in the village. However, he is a kind and generous man and has no history of violent behavior."

Holmes continued, "Did your husband have any prior acquaintance with the victim, who you indicated was a local man?"

She continued, "That is part of the problem. Pound is a clerk in a boat chandlery. He has been courting our daughter Mary, and my husband is very much opposed to the match. He is a fine man, and, in spite of her father's opposition, I think and personally hope that they do marry."

Holmes tented his fingers together and asked one final question. "Was a weapon used, such as a club or a heavy stick?"

"That is another problem. No weapon was found, but my husband had a slight stroke of apoplexy 3 months ago. Fortunately, he had a swift recovery, but now uses a heavy walking stick in his right hand. Our constable believes it capable of rendering a severe blow." She pulled out a handkerchief to wipe some tears, and finished with an entreaty. "Please, Mr. Holmes, we need your help."

Holmes consented to come, there was a brief discussion about the village and about local accommodations, and she left.

Holmes turned to me and asked if I could take the morning express and spend a few days at Braxton taking the salt air. He also added, "The account of the event is not convincing that the Squire is innocent."

I said I was pleased to accompany him. Holmes absented himself with an excuse that he had a few errands.

It was a pleasant train ride the next morning and we then settled in a delightful inn. The village was situated on the western side of an inlet protected from the North Sea by a promontory north of the village, which then faced west and provided a quiet cove. On the promontory was the Fletcher manse. It was surrounded by extensive fields with an occasional crofter's cottage. Holmes and I took a walk to examine the surroundings. From the manse there was a lane that divided into a road, on the right called the Harbour Road and on the left named the Town Road. On the Harbour Road were fishmongers, shipping offices, and the boat chandlery at the end of the road. The Town Road was the main road with the usual shops and the Braxton Inn where we lodged.

We finished our outing with a visit to the constabulary, where the Squire was held. Constable Duncan was a large, jovial man who was willing to share information with us. Holmes, always attuned 
to the situation, shared pleasantries with him before gathering information.

When questioning began, the constable lost his joviality, and said, "I have known the Squire for 30some years, and, although our stations in life are much different, he and I were grand friends, joking and sharing many a pint together. It is not a good time for me."

Holmes commiserated, but pursued his questioning. "What did the young clerk Pound give in evidence?"

"He was out for a few hours after the blow, but then gave me what he remembered. At the close of the day in the chandlery, he takes the money up the street to one of the shipping offices where they have a safe. It is a well-known fact in the village. However, the junior clerk had already taken the money up to the safe. As Pound was coming out of the chandlery door, he was partly blinded by the setting sun and only remembers a large man in a gray coat, and then the blow fell. The other clerk heard the commotion, ran out of the door, saw Pound on the pavement, and then saw the Squire in a gray coat and carrying a heavy cane walking down Harbour Road. I was summoned and asked the Squire what he was doing there, as I never saw him in this area. He was confused and could not give me a straight answer. $\mathrm{He}$ and his Missus often walk from the manse down Town Road and eat at the inn. That evening, she had done some shopping and he was to meet her there."

Holmes said, "Surely, you do not suspect the Squire of common thievery?"

The constable quickly answered, "Oh, no, but you know there was bad blood between the two?"

Holmes nodded, and said, "Yes, Mrs. Fletcher told me of the romantic liaison. Could I have a few minutes with the Squire?"

The constable was most accommodating, and left them alone for several minutes.

Holmes emerged from the small cell, and spoke briefly to the constable. "I know that the Squire is innocent, but we must find the culprit. I have a plan, but I will need you to help." Again, he and the constable spoke a few minutes, and then Holmes and I went back to the Braxton Inn.

Back at the inn, Holmes turned to me, and said, "Watson, the constable and I have planned a scheme to trap the culprit and clear the Squire. Unfortunately, we need some bait and that is where you are involved. You are perfectly free to refuse me when you hear of our plans."

I quickly interrupted, "Holmes, you can be assured of my help, for I know you would not risk my safety."

He went on to explain, "Again, I am indebted to you. Here is a 5-pound note. Go into the King's
Arms on Harbour Road and buy drinks all around. A few remarks about your own financial good fortune would not go amiss. Then promptly at 7 o'clock, when the street is deserted, walk slowly down away from the pub. We hope to root out the criminal. The constable and I will be secreted on the street and will instantly intervene. Again, will you do it?”

The scheme worked well, and, after only a minute or two, I was accosted by a large man in a gray coat who demanded my wallet. The shrill whistle of the constable immediately frightened him off, and he was soon captured. It turned out that he was wellknown for his criminal activities in the fen country, and he admitted to the assault on the clerk.

On our train ride back to London, I inquired of Holmes, "You sorted out a most distressing affair. Most of it is quite straightforward, but how were you so convinced of the Squire's innocence?"

Holmes chuckled. "I would like to say it was elementary, but it was not. Perhaps you remember one of my earlier mysteries, which you fancifully entitled 'The Case of the Reed in the Breeze.' You will also remember at that time I dined with my brother Mycroft and with Doctors Gowers and Jackson. Our conversation was most widespread and animated, or as animated as one can be in the Diogenes Club. I recalled some remarks by Jackson, which provided me guidance. Jackson talked about the duality of the brain. My errand prior to coming here was a visit to a medical library. There I found my information. You will recall that Mrs. Fletcher said that her husband had suffered a slight stroke a few months ago, and now he used a cane in his right hand. It is my observation that the cane is carried in the arm opposite to a lamed leg to provide support. Thus, if my elementary knowledge is correct, this would mean that the right side of the brain must have suffered the damage. This led me to my peregrinations through the medical literature fortified by Dr. Jackson's remarks."

Holmes took a folded piece of paper, and explained he copied it from a case report by Jackson. Holmes said, "Watson, let me preface my reading by pointing out that Jackson, at our dinner, had put forth the idea that the right side of the brain played a special role in visualizing space, in contrast to the left side, which had a special role in language, as noted by the French surgeon Broca in 1864. He explained his reasoning on the basis of his observation of patients with right hemisphere damage as suffered by the unfortunate Squire. Jackson called this peculiar condition with change to the right side of the brain as imperception. Now, let me read one of the cases reported by Jackson in the Royal London Ophthalmic Hospital reports of 1876;8:434-444. This was in a 
57-year-old woman who had a tumor of the right hemisphere of the brain. 'Patient had been a healthy woman up to the time of her present illness. Has never had rheumatic fever. For 2 months before this illness set in she had pain in the head and "neuralgia," but never did anything odd until about Christmas time. She was going from her own house to Victoria Park, a short distance and over roads that she knows quite well, as she had lived in the same house for 30 years, and has had frequent occasion to go to the park; on this occasion, however, she could not find her way there, and after making several mistakes she had to ask her way, although the park gates were just in front of her. When she wished to return she was utterly unable to find her way, and had to be taken home by a country relation to whom she was showing the Park for the first time. When she got home she seemed as usual...' Now, Watson, is this not reminiscent of the Squire's problem?"

Holmes continued, "I confirmed my suspicions with my visit to the Squire. He seemed quite normal until I showed him a map of the local region, which he had surveyed in the past. He had great difficulty in tracing out routes to the local villages, which he had visited many times. It was not definite proof of his disability, but raised my suspicion enough to proceed with our little subterfuge."

Holmes thought for a moment, and went on, "Watson, I must also admit an error. You will remember in your original account of meeting with me in 'The Study in Scarlet,' I noted that one must stock his brain, or brain attic, with useful information and not useless information as it would crowd out the other. I must revise that as you must select certain information to go in one side but not the other. But I digress. Mrs. Fletcher informs me that the Squire made his peace with Pound, and the Fletchers provided a rather munificent emolument for my services, which I will share with you for your gallant effort."

I demurred, and chuckled, "Your admission that you will revise your thinking is reward enough, Holmes."

Holmes laughed, and said, "Then, Watson, we will see if a fine white wine and a Dover sole Meuniere can compare with a pint of ale and fish and chips that we had at our last lodging. Providing, of course, that we can find our way." 


\title{
Neurology
}

\author{
The case of the misguided Squire \\ Robert J. Joynt \\ Neurology 2009;73;154-156 \\ DOI 10.1212/WNL.0b013e3181ad53b1
}

\section{This information is current as of July 13, 2009}

\section{Updated Information \&}

Services

Permissions \& Licensing

Reprints including high resolution figures, can be found at: http://n.neurology.org/content/73/2/154.full

Information about reproducing this article in parts (figures,tables) or in its entirety can be found online at:

http://www.neurology.org/about/about_the_journal\#permissions

Information about ordering reprints can be found online:

http://n.neurology.org/subscribers/advertise

Neurology ${ }^{\circledR}$ is the official journal of the American Academy of Neurology. Published continuously since 1951, it is now a weekly with 48 issues per year. Copyright. All rights reserved. Print ISSN: 0028-3878. Online ISSN: 1526-632X.

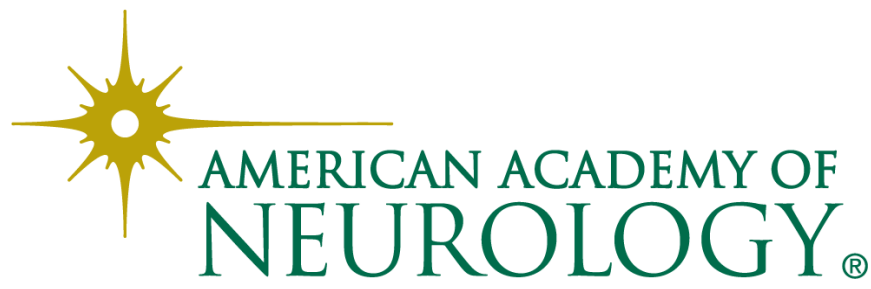

